\title{
Remembering Past Environments: Identity, place and environmental knowledge in the Tumut region of New South Wales
}

\author{
Ruth Lane
}

If someone spoke about Black Andrew, well the older people and the ones that pass it on, they'd know exactly where it is but now it's no more. And it'll probably be given just another name, a forestry number. Just a number now. ${ }^{1}$

This comment was made by Joan Kell, a long-term resident of the Tumut region of New South Wales. Black Andrew was a pastoral property which was purchased by the softwood company, Sintoff Pty. Ltd., in 1991 and subsequently planted to pine. The spread of pine plantations is the most recent of a sequence of land-use changes in the Tumut region and Joan Kell's comments reflect a widespread concern among local people about their changing landscape. Name changes connected with new forms of land use mean that it is no longer possible for local people to talk about the country in the way that they used to.

Local perspectives on environmental change are related to personal histories and identities that are vested in the landscape and the relationship between identity, place and environmental knowledge is affected by dramatic changes in land use. The quote above suggests that the transformation from pastoral lands to pine plantations entails a linguistic change that alters the relationship between people and land, distancing them from land which was once familiar. A better understanding of the links between identity, place and environmental knowledge has valuable applications for land management, particularly in the context of community consultation about environmental issues.

The fieldwork that this paper draws on was conducted between 1991 and 1993 as part of a master's thesis in geography, titled 'Local Environmental Knowledge and Perspectives on Change: A case study in the Tumut region of New South Wales'. ${ }^{2}$ The aim of the project was to gain an understanding of how people perceive environmental changes in country that they have lived in for many years, in order to inform consultative processes about land management and land use change. Two aspects of local knowledge emerged: the detailed memories of changes in specific places at specific

1. Tape transcript IK $053-4$ p. 14. 
times (ie. a knowledge based on empirical observation), and a more emotional experience of changes over time and responses to them. This paper deals with the more subjective aspects of local environmental knowledge and its connection with a sense of place and identity. In a separate paper ${ }^{3} \mathrm{I}$ address the potential of local knowledge to inform scientific understandings of relationships between vegetation change resulting from changing land use and changes to the shape and flow of watercourses.

According to anthropologist Keith Basso, ${ }^{4}$ there are three ways in which local communities involve themselves with geographic landscapes. These are observation, utility (ie. they may modify the landscape to suit their needs) and communication (ie. they formulate descriptions and other representations and share these socially). Basso is particularly interested in the symbolic aspects of landscapes, the shared cultural conceptions that are evoked in talking about them. Some aspects of anthropological studies such as Basso's, which focus on indigenous knowledge, also have relevance to colloquial knowledge of places among non-indigenous people. Knowledge of place names and some of the stories associated with them bind together different groups of people within local communities.

The Tumut region began the transition from a landscape primarily influenced by Aboriginal land use to one dominated by European land use in the 1820s and 1830s, when early pastoralists with sheep and cattle usurped the Wiradjuri, Ngunnawal and Walgalu peoples from the Tumut River valley. Since then, land use in the region has undergone successive phases that have impacted on the type and extent of vegetation cover and on the shape of creeks and rivers. The general trend has been towards more intensive land use, assisted by government incentives for closer settlement and by changing agricultural technology. There are some recent exceptions to this trend, however, where intensive land uses such as dairying and millet cropping have been replaced by grazing beef cattle. Land-use patterns have changed dramatically within living memory. Pine plantations have replaced native forests and pasture lands and a dam on the Tumut River at Blowering has altered the patterns of stream flow and flooding.

I recorded interviews with approximately fifty people who had lived most of their lives in the Tumut region, and spoke with many more in less formal situations. I deliberately sought out informants who encompassed a range of different backgrounds and life experiences in this region because I wanted to explore the ways in which differing life experiences reflected the kinds of memories people had of environmental changes over time. There were equal numbers of men and women and a mix of people who had never held land and people linked to land-holding families. I focused on ten of these people as key sources. Two of the ten, Vince Bulger and Minnie Freeman, were Kooris

2. Lane 1995. I was inspired to undertake this study because of work I was involved in in my role as a curator at the National Museum of Australia. We were preparing a travelling exhibition about the human and environmental history of the Murray-Darling Basin, largely funded by the Murray-Darling Basin Commission to further its agenda of education for sustainable land use. Local communities were involved in the development of the exhibition and contributed their own interpretations of the history of their regions and environments.

3. Lane 1997a.

4. Basso 1988, p. 100. 
who had links with Brungle station, commonly referred to as 'the mission', which operated as a reserve for Aboriginal people under the auspices of a government appointed manager until 1942. John McGruer held a property on the Tumut River flats south of Brungle and adjoining Pine Mountain where his family had been since 1860. Aubrey and Gloria McGillveray were more recent arrivals to the Tumut River flats, with Gloria's family taking up a small dairy farm at Tarrabandra on the western side of the river in the 1920 s.

Mark and Sheila Garner, Beryl Margules and Joan Kell had all lived in the higher country around Tumorrama. Mark Garner and Beryl Margules both came from pioneering settler families that owned land in the higher country around Tumorrama. Joan Kell grew up on a 200 acre ( 81 ha) block which her parents selected at Tumorrama. Jack Herlihy and his sister-in-law, Hazel Herlihy, were the last landholders left at Argalong, to the south of Tumorrama. The Herlihy family had been significant landholders there for several generations but most of this land is now covered with pine plantations. Tommy Kent worked at Argalong as a miner during the 1930s and 1940s, earning a rough living extracting small quantities of gold from the creeks.

Despite the very different histories of Aboriginal and non-Aboriginal people in the region, I asked similar questions of each, as I was keen to establish an approach to local environmental knowledge and perspectives on change that could accommodate all local people. While I believe this approach has practical value for land management, it may emphasise commonalities between Aborigines and settlers where a different approach could have shed more light on the differences which I sensed were present, but found difficult to define.

Interest in history is a common response to the loss of remembered places. Peter Read discusses this in relation to the responses of residents of the town of Adaminaby, on the western side of the Snowy Mountains, some years after it was inundated by a dam in $1956-57$ as part of the Snowy Mountains Scheme. ${ }^{5}$ Most of the people interviewed were no longer engaged in the land use they had been involved in for most of their lives. Their perspectives, now that they were no longer using the land for economic purposes, were attuned to conservation and aesthetic values rather than economic ones. They had become more aware of the history of the region and were concerned that memories be recorded before they were lost.

All ten key informants felt very strongly about particular parts of the region, some steadfastly holding out against land-use changes with which they disagreed. Their ages ranged from 65 to 83 years, and their childhoods and earliest memories spanned the years from 1920 to 1940 . There were patterns in the kinds of stories these people related about their lives in this country and those of their families, which provide clues to the way that their memories of past environments were structured. I have grouped their stories into three rough categories-ancestor stories and genealogical landscapes, journey stories, and stories of labour and hardship.

5. Read 1992. 

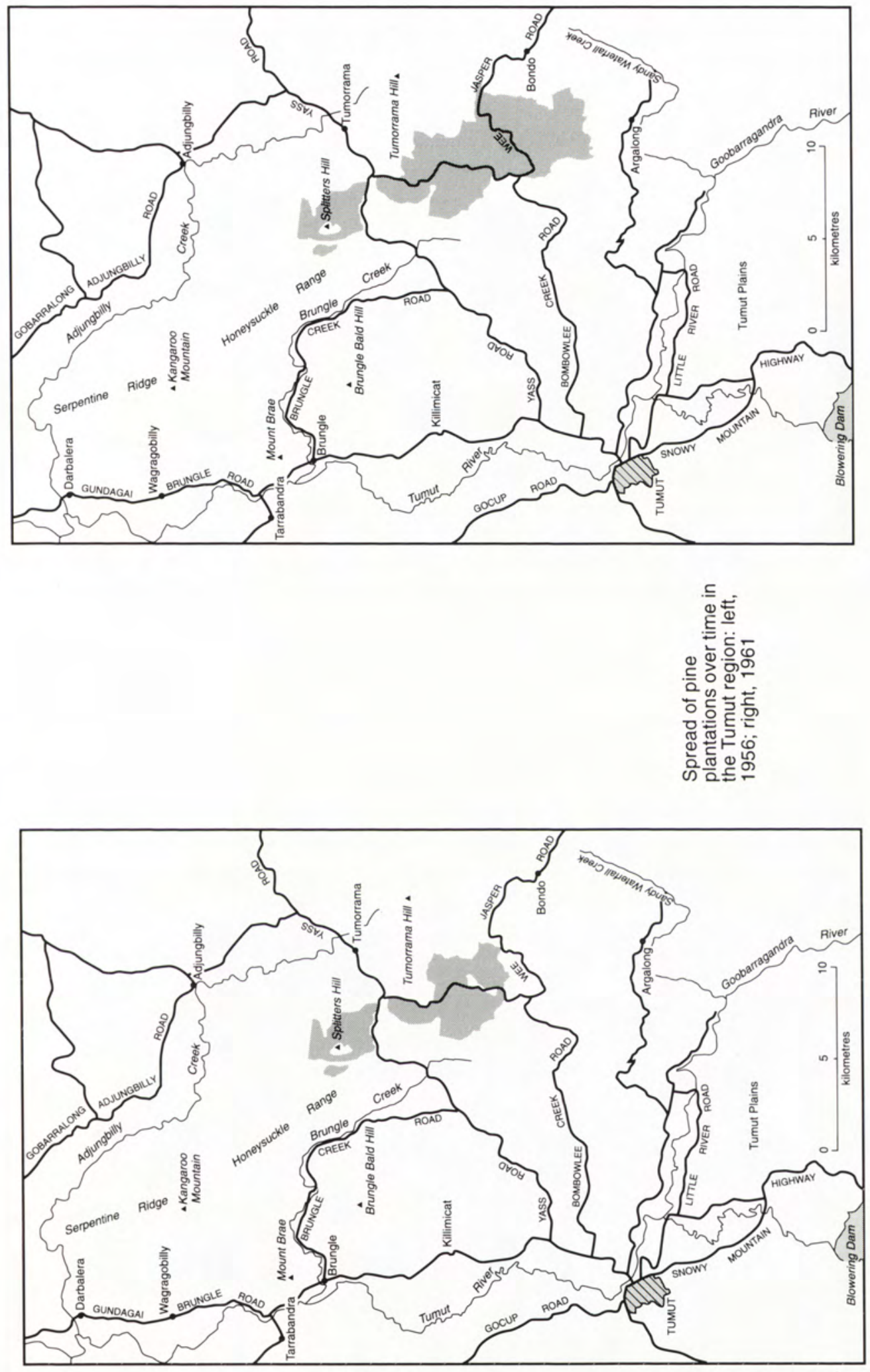

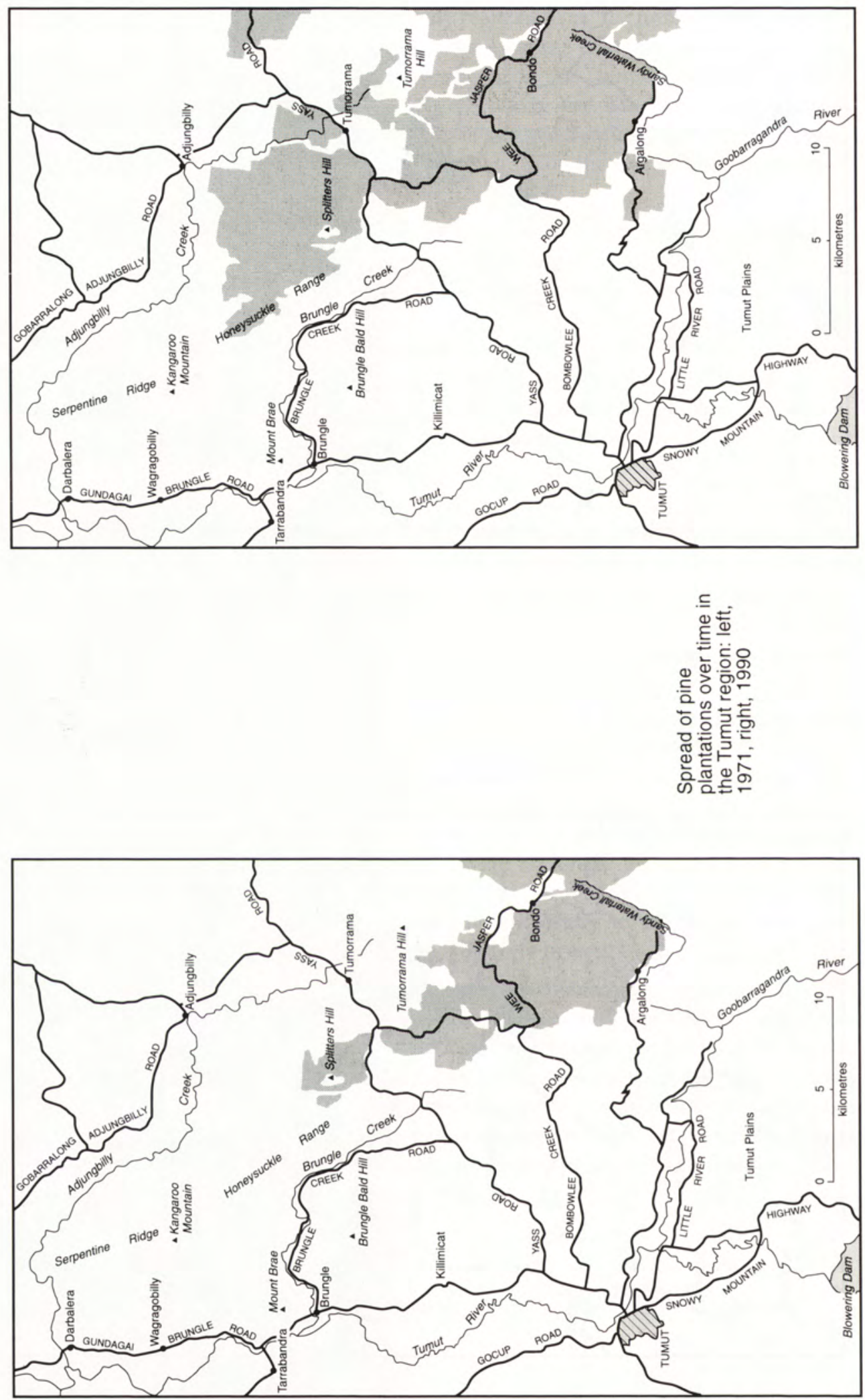


\section{Ancestor stories and genealogical landscapes ${ }^{6}$}

At our first meeting, most of the people interviewed volunteered an account of how their families came to be in the region and which places were significant to their families' histories. These stories took different forms, but I broadly classed them as 'ancestor stories'. Most of my non-Aboriginal informants were connected in some way with landholding families, some of whom had come to the region in the late nineteenth century. Recounting the stories of their relatives' journeys to the country served to reinforce their own position and identity in relation to the land. Mark Garner related a story about an epic journey made by his ancestors, who travelled from Yass to Tumorrama and camped inside a hollowed-out tree on the way. Beryl Margules explained how her grandfather had established the first mail run in the district from Tumut to Bookham and how this had involved lengthy journeys on horseback through rough country, fording both the Goodradigbee and Murrumbidgee Rivers.

Despite or because of the social disruption caused by the removal of Aboriginal children from their parents, there was great interest among Kooris in mapping kinship lines and in tracing geographical movements of their ancestors. Vince Bulger, who had spent portions of his childhood living with his family on Brungle station, told how Aboriginal elders at Brungle station had spoken about a battle that was fought before white settlement between Ngunnuwal and Wiradjuri tribes. The Wiradjuri were returning to the high country after holding initiation ceremonies at Mudjarng (now known as Pine Mountain) when they were ambushed by Ngunnuwal who wanted to rescue a woman who had been kidnapped by Wiradjuri men. Vince Bulger was very interested in mapping out this story in the landscape. He thought that the most likely spot for the ambush was the place where the road follows the creek through a narrow gorge between Millers Hills and Honeysuckle Range. Surveying the landscape, he picked out the path that would have been the best route for walking this way.

The accounts people gave of journeys made by their ancestors have symbolic significance. By referring to these journeys they define their own identity in relation to the land. The country and places they refer to form part of their genealogy. In this way, the physical landscape is related to family history. It gives a dimension to each person's identity that connects his or her life to a deeper time frame, which is mapped with reference to the features of the landscape. American anthropologist Stephen Foster describes a similar emphasis on the importance of land and history to the expression of personal identity among residents of Ashe County in North Carolina:

The land brackets history, is its theatre, its ground. Land situates the transit of the person within history; the person is encompassed by the history of the land and place. Pioneering ancestors came to the land and there gave birth to their descendants. Present-day descendants expect eventually to be laid to rest in the land, while hoping for history to continue to flow on through the land once their own lives are over. Thus blood and family lines are inextricably interwoven with the history of land and place. ${ }^{7}$

6. The term 'genealogical landscape' is drawn from the title of a paper by Allen 1990.

7. Foster 1988, p. 168. 
The sites of old graveyards aroused strong emotions. Burial places were among the most powerful symbols of past lives in the country and of the connection between people and the land, and past and present generations. The cemetery where Aboriginal people were buried at Brungle was listed on the Register of the National Estate in 1991 in recognition of its significance to the Koori community. Vince Bulger explained that his father and grandfather were both buried there and that when he died he wanted to be buried alongside them. However one of his sons, also named Vince Bulger, remarked that no-one really knew the sites of all the Aboriginal graves at Brungle and that it was quite likely that unmarked graves were dispersed over the site of the old Brungle station. Beryl Margules, who had spent her childhood and much of her adult life on her father's property in the plateau country around Tumorrama, expressed concern about the unmarked graves in the old cemetery at Tumorrama. It was the first cemetery that had ever been used in the Tumorrama district, but no one had been buried there for sixty-five years. She explained that many people, mostly miners or members of poorer families in the district, were buried there. More wealthy families used the cemetery in Tumut.

\section{Journey stories}

The journeys people recounted from their own personal experience helped to recall discrete periods in their lives. Retracing these journeys brought back memories of the people associated with them, and prompted comparisons of the current environment with memories of environmental features which have changed over time. For example, Joan Kell's journey to school on her pony was associated with her childhood at Tumorrama. A sudden snowstorm could turn a regular journey to school into a perilous adventure. Joan Kell remembered turning back home one morning because she felt it was too cold to continue safely. Her family held a small property at Tumorrama and was forced to sell up because their block was not large enough to support the family adequately. Tommy Kent and his brother and father made a meagre existence from gold mining in the creeks around Argalong, on the lower slopes of the Snowy Mountains. They used to ride bicycles from Argalong to Tumut when they needed to replenish supplies in the 1930s. Tommy Kent became so familiar with this route that fifty years later he was able to describe the different soil types along the way. He had acquired his knowledge of soil types while working as a gold miner in the district.

Beryl Margules described how she used to drive stock from the markets at Brungle up to the family's property at Tumorrama. She pointed out a particular hill on Honeysuckle Range beside the old stock route, which, she explained, had a very different vegetation on it to any other in the region. 'Different soils, different rocks,...I don't know why; I'd go over there when the heather came out. ${ }^{8}$ Seeing the hill prompted Beryl to relate a story about a schoolteacher who gave birth to a baby girl when the 'heather' was in flower and named her 'Heather'. This area has since been identified by botanists working for the National Botanic Gardens as having several rare plant species and is likely to be made a reserve for nature conservation (Geoff Butler pers. comm.).

Minnie Freeman spent her early childhood on Brungle station, but like many Aboriginal girls of her generation, was taken away from her family at a young age and

8. Tape transcript 050-1, p. 14. 
placed in the Cootamundra Girls' Home and only retained dim memories of her parents. She later returned to Brungle with her husband, Ned Freeman. The country Minnie Freeman knew best was the vicinity of the old Brungle station and the road between Brungle and Tumut. Over the years she had traversed this road on horse back and by bicycle. Now her relatives drive her back and forth when she needs to visit Tumut. She observed changes in the Tumut River and its anabranch Nimbo Creek since the construction of Blowering Dam and described the impact that these changes had on Kooris living at Brungle.

\section{Stories of labour and hardship}

Another kind of story that was often recounted when people spoke about their memories of the country was one of physical labour or hardship. Like the journey stories, these also referred to a physical experience of the country associated with former times. Physical work was one of the ways in which people changed and were themselves changed by their physical environment. Memories of labour were usually related to particular forms of land use and were often associated with memories of people they had worked with. Minnie Freeman and Vince Bulger, who lived on Brungle station when it was administered by the Aborigines Protection Board with strict rules about conduct and movement, were made to work for their rations as were all the Kooris living there. The men mostly did station work and the women worked in the dairy. Vince Bulger expressed mixed feelings about this period. While he resented the authoritarian regime, he was proud of the fact that the community supported itself through collective labour and had some warm memories of a time when Koori families lived together and maintained some links with older generations.

Sheila Garner and her husband Mark Garner purchased a small block of land at Tumorrama after their marriage in the late 1950s and lived there throughout the 1960s. During this period when their three children were young, Sheila Garner learnt to make cakes using the slow burning timbers that were all that was available and impressed women from lower lying country who had access to more suitable timber. Some of the people interviewed had been involved in clearing native timber at Tumorrama for pastoral purposes. Vince Bulger described the labour he put into clearing fallen timber while working as a stockman on Red Hill Station in the 1940s and 50s, and clearly enjoyed recalling stories about men that he had worked with. Beryl Margules remembered helping her father to clear native trees from a portion of their land at Tumorrama, which was later sold to the Forestry Commission and is now planted with pines. It upset Beryl that the marks of their labour had since been extinguished by the new land use.

Some people also spoke about the physical labours of their ancestors in the country. Both Jack Herlihy and Mark Garner, descendants of pioneering landholders at Argalong and Tumorrama respectively, described with a sense of awe the labours of their ancestors in clearing the country of virgin forests. One of Jack Herlihy's complaints about the Forestry Commission and its impact on the landscape was the way that the marks of the labour of early European settlers in the country were extinguished: 
It's a sort of an automatic thing. There's no sentiment or any attachment to what the pioneers did in the early days. They've just completely wiped them altogether. $^{9}$

For similar reasons, Tommy Kent was upset to find that one of the gold mine shafts at Argalong had been filled in. The old shaft was evidence of the labour of the miners who used to work it. His memories of life as a gold miner at Argalong in the 1930s and 1940s were very much memories of hard work and harsh living conditions.

Joan Kell pointed out the old post and rail fences along the roadside as we drove up to Tumorrama. To her the old fence posts triggered memories of the skills and labour that went into making them in the days when everything was done manually. Mark Garner related stories passed on to him by older relatives that indicate that early pastoralists had deliberately drained the swamps at Tumorrama by digging channels. A heavy lig was hitched to a team of bullocks and dragged through a swamp until water flowed freely through the channel created. It was arduous work and stories were passed down through Mark Garner's family about the endurance of particular bullockies.

There was a great deal of consensus among local people about changes to creeks in the higher country of Tumorrama and Argalong. In general, they believed that creeks which had their catchments converted from pastureland to pine plantations had become silted and in some cases had a reduced flow. Sheila Garner went to school at Argalorg in the 1930s. When she returned there recently for a school reunion she was totally disoriented among the pines and could hardly recognise Big Sandy Creek because it had become much smaller and narrower than it used to be. Hazel Herlihy recalled an incident from the 1950s when her young daughter made a dangerous crossing of Little Sandy Creek when it was in flood. She then explained that such floods have not occarred for many years and related this to the reduced run-off from pine plantations. 10

\section{Aboriginal relationships to land at Brungle}

Aborignal perspectives on land around Brungle highlighted the very different histories of Aboriginal and non-Aboriginal people in this country. Vince Bulger and Minnie Freeman had both lived on Brungle station during their childhood and had been compelled to leave against their will. The life at the Station had involved a social network, a home site and shared labour. Although there were many unhappy memories associated with this period, the land itself remained very important to these Kooris, as a site of shared memories and links with past traditions. All the areas of Crown land in the vicinity of Brungle were significant places for local Kooris, however the land which used to be Brungle station was the most contentious area at Brungle. Brungle station consisted of 365 acres (148 ha), classified as Crown land and administered by the Aborigines Protection Board. All but 16 ha of this was leased to a local grazier in 1956 under a ninety-nine year lease. It remained a source of great resentment for Vince Bulger and other Kooris I spoke with, who regarded it as 'Aboriginal land' or simply 'our land'.

9. Tape transcript 049, p. 11

10. See Lane 1997a for a more detailed analysis of such comments which relates them to scientific understandings of the impact of changes to vegetation in catchments to surface run off. 
This deep felt sense of ownership seems to be similar to that held by Aboriginal people in regard to old reserve lands elsewhere in south eastern Australia and differs to perceptions of ownership held by non-Aboriginal people. Historian Heather Goodall tracks the specific interpretation of legal title to reserve lands back to their creation as designated farming reserves in the late nineteenth century, and their description by officials at the time as "land grants'. ${ }^{11}$ She analyses the complex sentiments about these lands as follows:

These beliefs about the reserves and their title represented a new layer of meaning about land, its ownership and its significance, which the experience of colonialism generated among Aboriginal landowners and which came to be inscribed onto the land itself. These concepts were not 'traditional', but they grew out of the strength of the emotional bonds between traditional owners and their lands, as well as continuing Aboriginal desires to organise their social future, their plans, residence and economy, around the land they regarded as their own... 12

She goes on to explain that,

the lands acquired a further layer of meaning which arose from the everyday experiences of their Aboriginal residents over decades. ... So the richness of daily life was experienced there repeatedly over those decades, and the memories of the everyday events, as well as the knowledge of the past meanings of the land, and the hopes for the future, were all embedded within the boundaries of those reserve lands. Thus an intense new web of significance and meaning was being laid down on these lands through this period of colonisation, adding to the traditional meanings for land. ${ }^{13}$

Goodall's interpretation seems to offer a good basis for understanding the complexities of Aboriginal relationships to land at Brungle.

Pine Mountain, just south of Brungle, is a local landmark because of its distinctive vegetation of black cypress pine (Callitris endilicheri). The black cypress grows only on the granitic soils of Pine Mountain making it a unique and eye-catching feature in the landscape. Known to local Kooris as 'Mudjarng', it was used by Aborigines living on Brungle station for initiation ceremonies. Vince Bulger pointed out that Mudjarng was the closest Crown land to Brungle (apart from the town common) and this may have been partly why the old people living on Brungle station used it for initiation ceremonies. He said that ceremonies were still carried out there up to the turn of the century. Vince Bulger himself had seen engravings on rocks there. He was keen to document these and to substantiate the area's wider significance to Kooris before he died, so that Pine Mountain could be claimed as Aboriginal land.

Pine Mountain has also attracted the attention of nature conservation agencies. In 1984, a report was prepared by New South Wales National Parks and Wildlife Service staff, apparently in response to an anticipated Aboriginal land claim, about both nature conservation values and Aboriginal cultural resource values of Pine Mountain. This report concluded that 'It is considered quite likely that management of the land by Aborigines as a "sacred place" will preserve its nature conservation and landscape val-

\footnotetext{
11. Goodall 1996, p. 102.

12. ibid., p. 103.

13. ibid.
} 
ues. Although it is recognised that there is no guarantee this will occur... ${ }^{14}$ In 1987, a report on Aboriginal sites in the Tumut Shire was prepared by National Parks and Wildlife Service archaeologist, Sue Feary, who drew on Vince Bulger's knowledge of the area for assistance. It included the comment:

The existence of the Aboriginal Mission at Brungle has facilitated the retention of some traditional knowledge, which points specifically to Pine Mountain Range as being a place of considerable significance. ${ }^{15}$

The acknowledgment by a government agency of the significance of Pine Mountain to the local Koori community may help to promote a broader recognition of the continuity between Kooris living in the region today. It acknowledges a history of Aboriginal land use which provides a far broader perspective of human history in the region than the brief period of pastoral land use.

Use of the Brungle Town Common was overseen by the Brungle Common Trust, a body of five members elected every three years under the auspices of the NSW Government in line with the Commons Management Act 1989 (NSW). This body was responsible for the day to day administration of the Common and, in conjunction with the Department of Conservation and Land Management, the development and implementation of a plan of management. Vince Bulger, however, felt that landholders effectively had more rights over use of the Brungle Town Common than Kooris. A sign on the gate forbade camping there and was a source of resentment to Vince Bulger. Aboriginal people had always camped along this stretch of Nimbo Creek, which had a continuity of Aboriginal use stretching back for thousands of years before Europeans entered the region. During the years when Brungle station was operating, Aboriginal women living there took their washing to the town common and washed it in the Nimbo Creek, spreading it out on fences and trees to dry. Minnie Freeman explained that before the dam there were little sandy beaches, the water was warmer and not so fast flowing, and children swam in the river. The common continued to be used by Kooris for fishing and picnics, although they now caught trout where once they caught native fish and crayfish. This aspect of use was permitted by the Trust and was clearly very popular on weekends when the weather was fine.

\section{Public rights to land in the Tumut region}

Public lands were a particular focus in the comments people made about changes to the landscape. With the successive waves of occupation and land use, land that was previously 'public' land has been effectively alienated from local people through incorporation into new land-use industries. For example, at Argalong and Tumorrama most of the tensions were connected with the Forestry Commission's acquisitions of land for pine plantations. Some land that had previously been Crown reserve, such as the school ground at Argalong and some parts of the travelling stock routes, had become pine plantations. ${ }^{16}$ Within the lifetime of my informants, transformations in land use had effectively restricted public rights of access to land and resources. Anger and grief were common responses. Many people felt that they had rights of use and access to these

14. Unpublished report, NSW National Parks and Wildlife Service 1984.

15. Report on Aboriginal Sites in Tumut Shire, National Parks and Wildlife Service, 1987.

16. Lane $1997 \mathrm{~b}$. 
places on the grounds of their family history in the country. Removal of these rights undermined aspects of their identity which were based on the past activities of themselves and their ancestors in those places.

Crown land reserves were particularly important in the lives of people who were not landholders. This was because they were more reliant on the resources of these lands than those who held their own land. Tommy Kent during his time as an itinerant gold miner at Argalong, and Kooris, Vince Bulger and Minnie Freeman, during their time on Brungle station, all experienced land in Crown reserves more closely and over a longer period than had landholders. Crown lands were also important as home sites for many people. At various times, people who could not afford to buy land were permitted to live on the reserve lands beside creeks. For example, Tommy Kent and his father and brother were able to lease a small piece of land for their hut in Ration Gully at Argalong during the 1930s. While working over creeks around Argalong for gold, they camped in the Crown land beside the watercourses. Vince Bulger and Minnie Freeman both recalled a Koori couple, Emma and Charlie Penrith, who were permitted to live on a small Crown reserve on the river bank near Brungle Bridge ${ }^{17}$ near to the property where Emma Penrith worked as a domestic servant. ${ }^{18}$

Those who did not own land sometimes indicated that they viewed reserves as places they could use for their own purposes and felt they had informal rights to use these places. Tommy Kent still used the reserves to collect fire wood. ${ }^{19}$ When he worked at Argalong in the 1930s, Tommy and his father and brother often killed native birds and animals to eat and supplemented this with steamed nettles for greens. The 'bush tucker' usually came from Crown lands. Vince Bulger described one reserve that we passed on the Wyangle Hill as 'reserved for me to get goannas' and explained how Kooris cooked goannas in underground ovens. ${ }^{20}$

All the local people I interviewed conveyed a strong sense of obligations and responsibilities connected with the maintenance of Crown reserves. They were frequently critical of Government Pasture Protection Boards or lessees whom they considered responsible for maintenance activities such as mending fences and controlling noxious weeds and animal pests. Aubrey and Gloria McGillveray, who ran a small property on the river flats at Tarrabandra across the river from Brungle, complained about weeds spreading along roadside reserves at Tarrabandra. There is a long history of complaints of this kind throughout Australia dating back as early as the 1850 s when landholders expressed concern about governments not controlling weeds in reserve lands. ${ }^{21}$ Landholders, local councils and Pastures Protection Boards are all obligated by the Local Government Act 1919 (No. 41) (NSW) to control weeds in lands for which they are responsible. ${ }^{22}$

17. Tape transcript 034, p. 6 .

18. This was probably during the $1930 \mathrm{~s}$ and $40 \mathrm{~s}$.

19. Tape transcript $055-6$, p. 5 .

20. Field Notes VB 5/8/93, p. 1.

21. Wright 1989, p. 86.

22. Parsons and Cuthbertson 1992, p. 4. 


\section{Conclusion}

The term 'community' has become topical in the rhetoric of ecologically sustainable development, along with frameworks for community participation in land management and restoration programs. Movements such as Landcare, which arose in rural Australia in the mid 1980s, and has since expanded to take in community based projects in urban areas, rely upon the motivations of local people to address land degradation problems in areas for which they feel a sense of responsibility. ${ }^{23}$ Landcare is related to a shift in government approaches to land management towards a greater emphasis on local people as agents for change, recognising that they have a greater capacity to address some forms of land degradation than have government agencies. However, the rhetoric of community consultation and participation needs to be matched by a better understanding of local environmental knowledge and local perspectives on environmental change.

Local people accumulate knowledge about the country both from prior generations and from their own experiences, and this knowledge is closely related to aspects of their identity which are vested in the landscape. Much of this knowledge is untapped by professionals in newer land-use industries, who usually have broader understandings about the causes and processes of change, but lack a knowledge base specific to the country which they manage. The perspectives of local people provide important information about both environmental and social impacts of new forms of land use. For some places, local people may be the only readily available source of information about changes to that land during their lifetime. Their recollections can be important supplements to sources that are more general, such as historical records and scientific understandings of the causes and processes of environmental change.

Clearly there are important connections between local environmental knowledge and perspectives on change and the sense of rights and responsibilities that people feel towards land. These sentiments are closely linked to personal, family and cultural history. In the Tumut region of New South Wales I detected both similarities and differences between Aboriginal and settler sentiments about land with the most obvious difference being in perceptions of ownership and rights to land. However, this paper has barely scratched the surface of a rich and complex web of emotions about land, history and identity. A better understanding of these interconnections and how they apply in different cultural and geographic contexts is very much needed in order to set environmental change in a human context and to relate changes occurring now to a long history of human influence and activity in Australian landscapes.

\section{References}

Allen, Barbara 1990, 'The genealogical landscape and the southern sense of place', in Sense of Place: American Regional Cultures, ed. B. Allen and T.J. Schlereth, The University Press of Kentucky.

Basso, K.H. 1988, '"Speaking with Names": Language and landscape among the Western Apache', Cultural Anthropology, vol. 3, pp. 99-132, American Anthropological Association.

23. Campbell and Siepen 1994, p. 27. 
Campbell, A. \& Siepen, G. 1994, Landcare: Communities Shaping the Land and the Future, Allen \& Unwin, Sydney.

Cornish, P.M. 1989, The Effects of Radiata Pine Plantation Establishment and Management on Water Yields and Water Quality-A Review, Technical Paper No. 49, Forestry Commission of NSW.

Foster, Stephen W. 1988, The Past is Another Country: Representation, Historical Consciousness, and Resistance in the Blue Ridge, University of California Press, Berkeley.

Goodall, Heather 1996, Invasion to Embassy: Land in Aboriginal Politics in NSW, 1770 1972, Allen \& Unwin, Sydney.

Lane, Ruth 1995, Local Environmental Knowledge and Perspectives on Change: A case study in the Tumut region of NSW, MA thesis, Australian National University.

Lane, Ruth 1997a, 'Oral histories and scientific knowledge in understanding environmental change', Australian Geographical Studies, vol. 35, no. 1, pp. 195-205.

Lane, Ruth 1997b, 'Frontiers of green: Pine plantations and local communities' in Australian Forest History III, ed. J. Dargavel, Centre for Resource and Environmental Studies and the Australian Forest History Society, Australian National University, Canberra.

Parsons, W.T. and Cuthbertson, E.G. 1992, Noxious Weeds of Australia, Inkata Press, Melbourne and Sydney.

Read, Peter 1992, 'Our lost drowned town in the valley: Perceptions of the inundation of Adaminaby 1956-57', Public History Review, vol. 1, pp. 160-174.

Wright, R 1989, The Bureaucrats' Domain: Space and the Public Interest in Victoria 1836-84, Oxford University Press Australia. 